\title{
ВІдгук
}

DOI: $10.31866 / 2616-759 x .2 .2 .2019 .187294$

\section{Валерій Гайдабура}

член-кореспондент Національної академії мистецтв України, доктор мистецтвознавства

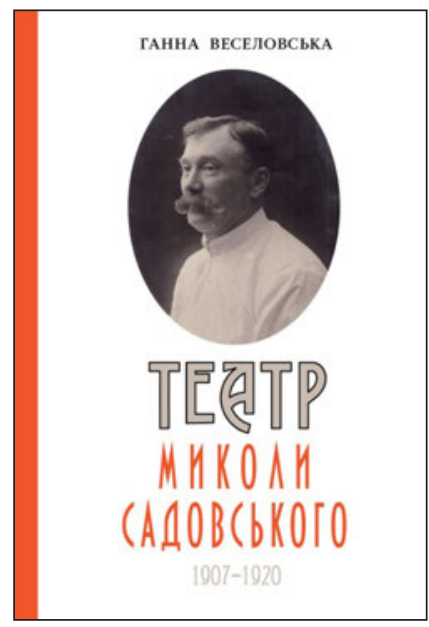

Веселовська, Г.І., 2018. Театр Миколи Садовського (1907-1920). Київ: Темпора.

Veselovska, H.I., 2018. Teatr Mykoly Sadovskoho (1907-1920) [Theater of Nicolas Sadovsky (1907-1920)]. Kyiv: Tempora.

Веселовська Г. І. Театр Миколи Садовського (1907-1920) : монографія. Київ : Темпора, 2018. 412 c.

Книжка Г.І.Веселовської про Київський театр Миколи Садовського зацікавить не тільки людей театрознавчого фаху, але й усіх любителів театрального мистецтва. Порадує як тих, хто цінує заглиблений аналіз театрального процесу, так і тих, для кого будь-яка «театральна тема на папері» провіщає задоволення суто естетичне - задоволення читання та переживання. Робота вражає тим, що дослідниця кинула виклик знаменитій книжці В. С. Василька про театр Миколи Садовського. Точніше - виклик тій безодні часу, яка не заохотила нікого після В. С. Василька заново осмислити тернистий шлях митця напередодні руйнівної революції. Такої роботи потребувала збагачена досвідом свідомість. Тепер $€$ варіант широкоаспектний, деталізований, настояний на багатій практиці українського театру, який відібрав, уточнив і підсумував внесок театру Миколи Садовського та його команди в скарбницю сьогоднішніх досягнень. У цій книжці авторка не зрадила своєму принципу - будь-яку тему обробляти з позицій універсалізму.

У неї грандіозний, логічно вибудуваний, мов академічний словник, потік інформації, який, навіть коли він слугує як матеріал побіжний чи допоміжний, вражає і яскраво «підсвічує» головне в розповіді. Книжку читаєш, мов захопливий 
роман з життя атлантів української сцени, і збагачуєшся розумінням того, що переосмислювати та переписувати варто не тільки історію радянського (тоталітарного) театру, а й театру більш давніх часів. Адже про нього засвоєно думки, не завжди об'єктивно сформовані за більшовицьких часів.

Усім небайдужим до творчо-організаційних здобутків українського театру рекомендуємо ознайомитися з монографією Г. І. Веселовської «Театр Миколи Садовського (1907-1919)». 